\title{
Simulation of Concrete Slab Behavior to Explosion
}

\author{
M. Shahib Al Bari ${ }^{1, \text { a)}}$, Januarti Jaya Ekaputri ${ }^{1, b)}$, Faimun ${ }^{1)}$, Julendra Bambang \\ Ariatedja $^{2)}$ \& Buntara S. Gan ${ }^{3)}$ \\ 1) Department of Civil Engineering, Faculty of Civil, Environmental, and Geo Engineering, Institut \\ Teknologi Sepuluh Nopember (ITS), Surabaya 60111, Indonesia. \\ 2) Department of Mechanical Engineering, Faculty of Industrial Technology, Institut Teknologi \\ Sepuluh Nopember (ITS), Surabaya 60111, Indonesia. \\ ${ }^{3)}$ Department of Architecture, College of Engineering, Nihon University, 1-Nakagawara, Tokusada \\ Tamura Machi, Koriyama City, Fukushima Prefecture, Japan 963-8642.
}

Correspondent : ${ }^{a}$ shahibalbari@gmail.com \& ${ }^{b}$ januarti@ce.its.ac.id

\begin{abstract}
Special structure prone to explosion requires special material. Identification of special material is required to find the right concrete properties. Researching material behavior using explosion test is costly. Therefore, prediction using simulation is needed. In this study, we use ANSYS Workbench as a simulation program. The explosion test model comprised a non-reinforced slab $500 \times 500 \times 50 \mathrm{~mm}$ and TNT cube. It was found that the compressive strength minimum of the concrete slab that withstand the explosion of 30 grams TNT was $20 \mathrm{MPa}$. The Young modulus affects to the concrete behavior using default RHT Concrete properties. It had instability against modified concrete properties when performing numerical analysis.
\end{abstract}

Keyword : infrastructure management, ANSYS, explosion, concrete properties.

\section{PRELIMINARY}

Special structure innovation develop continuously. As the name implies, these structures have additional ability. One of ability is a special structure prone to explosion. Bunker and armory are the example of special structures which are designed to resist blast load. The purpose of the bunker is to protect civilians from hazardous explosion. The armory is designed to provide protected location where armies gather and store ammunition and supplies. Explosion-proof material is needed to reinforce those structures.

It is mentioned in the Basic Principle of Infrastructure Asset Management, that all significant risks against infrastructure must be well considered (Suprayitno \& Soemitro 2018; Suprayitno \& Soemitro 2019). Meanwhile, the risk of experiencing terorist's bom explosion is real, for public civil building, such as the malls, the hotels, and others. Nowadays, certain building must be designed against bomb explosion risk. (FEMA 2003; Koccaz, Sutku \& Torunbalci 2008; Remennikov \& Carolan 2006). Therefore, understanding the effect of the bomb explosion to building infrastructure is necessary.

Explosion is a rapid burst of energy that releases shock wave, the heat wave and gas. Shock wave propagates through a medium. It contains high pressure from explosion. This pressure decreases as the shock wave propagates. The blast load is divided into two main groups according to the confinement of explosive charge: confined explosion and unconfined explosion (U.S. Department of Defense, 2008) . Unconfined explosion is divided by the location of explosive charge and structure: Air burst explosion and surface burst explosion. Air burst explosion is an explosion that occurs on air releasing shock wave without any amplification from reflected wave. Normally, the shockwave expands on any direction spherically. Surface burst explosion occurs on surface that produce reflected wave. This 
reflected wave amplifies with the initial wave. Due to the reflection on surface, it expands in hemispherical shape. In this study, air burst explosion is selected to prevent amplification from reflective wave.

The blast wave is characterized by ascending rapidly from ambient pressure to peak incident pressure Pso. This pressure travels radially with diminishing velocity. As the blast wave expands, the pressure decrease and the duration increase. At any point, the pressure disturbance make the shape as shown in Figure 1. The shock wave increases the air pressure on any location at ta time. After that, the peak incident pressure decreases into the ambient pressure in time to which is the positive phase duration. The negative phase which has the longer time than positive phase is the phase when the air pressure fills the void into the ambient pressure. Negative phase is less important than positive phase, thus the negative phase is ignored.

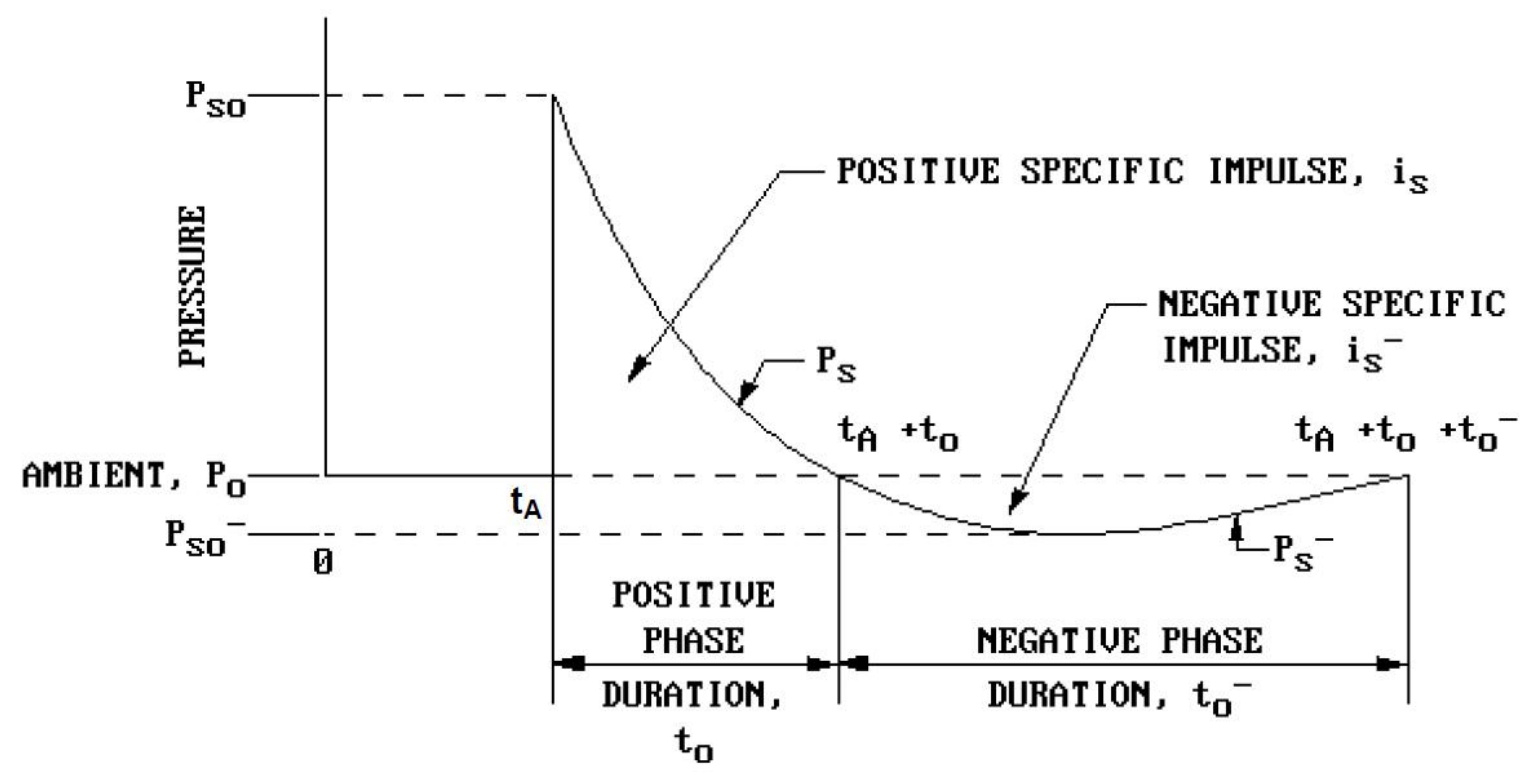

TIME AFTER EXPLOSION

Figure1. Pressure time graph of the blast wave for air burst explosion

Calculating peak incident pressure $\left(P_{o}\right)$ is hard to achieve without the program due to the duration of this pressure. UFC 3-340-2 (U.S. Department of Defense, 2008) provides graph to Figure out the incident pressure. The graph requires a parameter to identify the distance and weight of the explosive charge. The scaled distance which is defined as $z$ is the ratio of range $(R)$ and cube root of the charge's mass $(m)$. The formula is described in Eq (1).

$z=\frac{R}{m^{1 / 3}}$ 


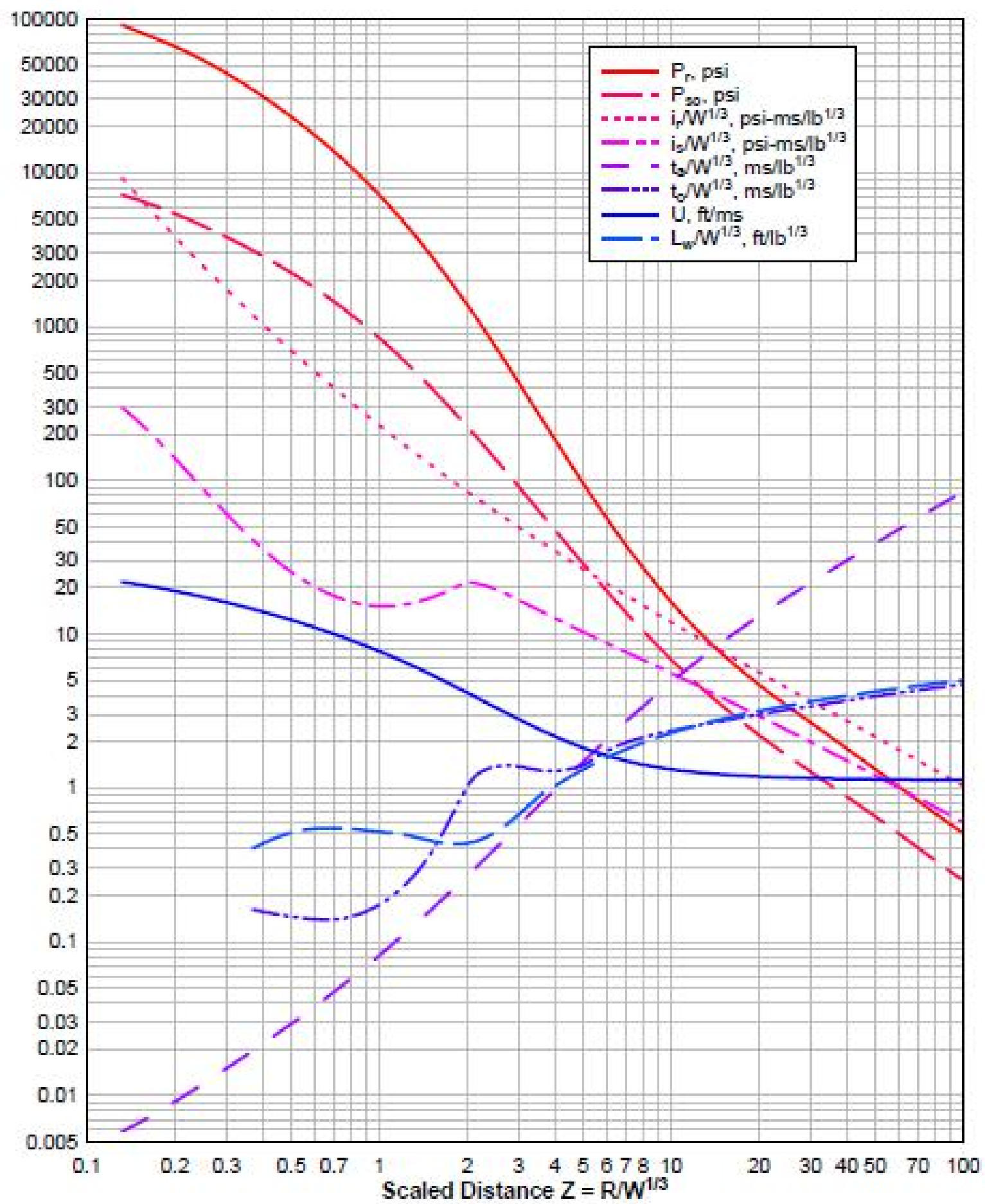

Figure 2. Positive phase graph using $z$ parameter for TNT charge

The explosion on building penetrates the weakest components (Ngo, et al., 2007). The weakest components are walls, glasses and doors. These components as a fragment is hazardous for everyone near the incident. If the explosive charge is large enough, it could blast off the slab. Although the inhabitants are not affected by the blast, they could fall off from crushed slab. Therefore, reinforcing slab with blast resistant material is necessary.

Explosion experiment is very expensive because it requires special facilities and permission. Therefore, the numerical analysis is needed to prevent the repetitive experiment. Nayel compared finite element result to experiment on concrete panel explosion test (Nayel \& 
Abdel-mooty, 2017). Wang applied finite element to predict concrete slab under contact explosion (Wang, et al., 2008). Shi proposed estimation formula to calculate blast pressure and reflection pressure on column structure based from finite element result and experiment (Shi, et al., 2007). These researchers demonstrate that numeric analysis compute the structure behavior to explosion accurately. However, specific concrete properties affecting the concrete behavior to explosion is needed. This study investigated how the numeric program simulates explosion on concrete by modifying the compressive strength, Young modulus of concrete and the mass of the explosive charge. However, this study limits only on the numerical analysis. This paper could become a reference for another research of concrete behavior to the explosion in the future.

\section{RESEARCH METHODS}

This study used ANSYS Workbench 19.1 as numerical analysis program. Its step is based on the manual (Lee, 2015). Trinitrotoluene was used as explosive charge material. This charge was put $0.5 \mathrm{~m}$ on top of concrete slab. Concrete slab $500 \times 500 \times 50 \mathrm{~mm}$ was made. This slab did not use reinforcement due to the lack of ANSYS ability to connect reinforcement and concrete as composite. The mesh connection between those was complicated. This problem made the program run slowly. CONC-35MPa from RHT Concrete (Riedel, et al., 2009) was used as slab material. All parameters excluding compressive strength and shear modulus in CONC-35MPA did not alter. If we have Young modulus $(E)$ only, it should be converted to shear modulus $(G)$ in addition of Poisson's ratio $(\mu)$. The conversion formula is described in (2).

$$
G=\frac{E}{2 \times(1+\mu)}
$$

Simulation was carried out in four steps. The first step was finding the minimum compressive strength which resist the explosion. The second was finding a minimum mass of the explosive charge on each model with different compressive strength. The third was comparing the concrete using Young modulus from formula (3) with concrete from experiment (Al Bari, et al., 2019) . The last step was validating blast pressure between numerical simulation and calculation taken from Figure 2.
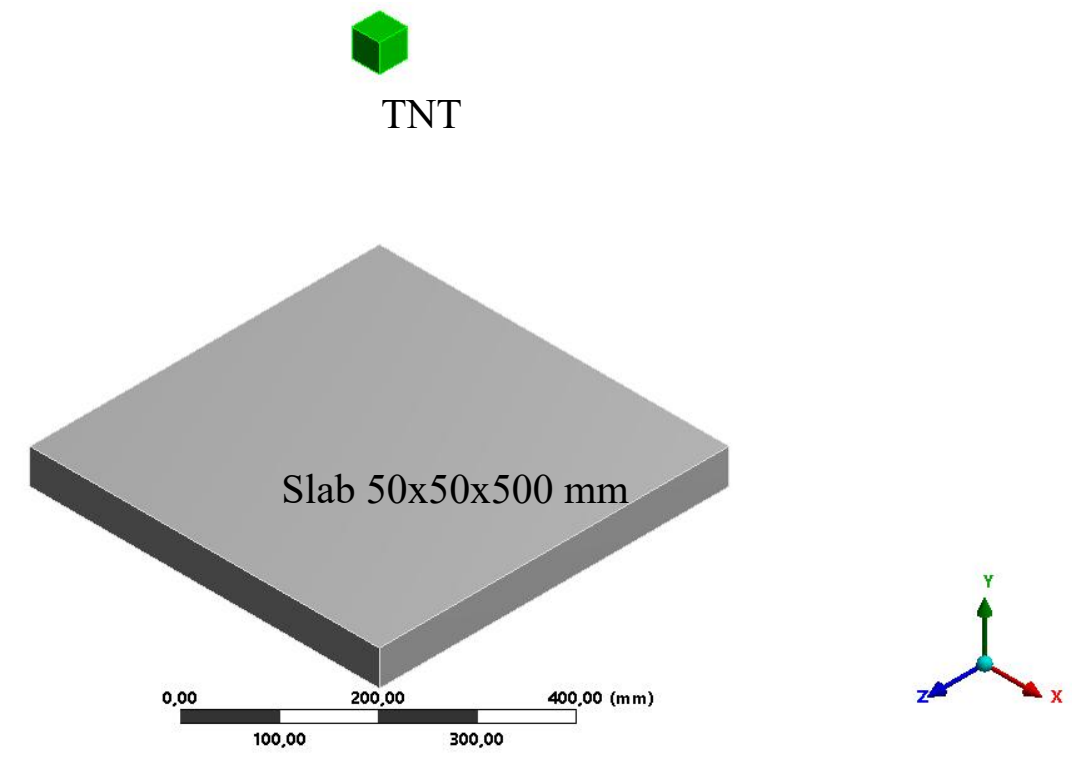

Figure 3. Explosion test model 


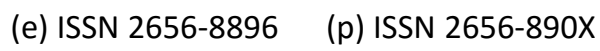
Journal of Infrastructure and Facility Asset Management - Vol. 1. Issue. 2, September 2019

\section{RESEARCH ANALYSIS}

\section{Numerical Result}

The first step used 125 grams TNT with the range of $0.5 \mathrm{~m}$. Compressive strength was modified. Young modulus was modified along compressive strength by using the standard formula from (3) in order to get ideal concrete (BSN, 2013). In CONC-35MPa did not provide Young modulus and Poisson's ratio. Thus, those variables should be converted into shear modulus. The value of Poisson's ratio was set constant at 0.15 . The value of Young modulus and shear modulus on each compressive strength is shown in Table 1.

$E_{c}=4700 \sqrt{f^{\prime}}$

Table 1. Young modulus and shear modulus on each compressive strength

\begin{tabular}{ccc}
\hline Compressive strength (MPa) & YoungModulus (MPa) & Shear Modulus (MPa) \\
\hline 20 & 21019 & 9139 \\
\hline 25 & 23500 & 10217 \\
\hline 30 & 25743 & 11193 \\
\hline 32 & 26587 & 11560 \\
\hline 35 & 27806 & 12089 \\
\hline 40 & 29725 & 12924
\end{tabular}

\section{F: $20 \mathrm{MPa}$}

Maximum Principal Stress

Type: Maximum Principal Stress

Unit: $\mathrm{MPa}$

Time: 2,5002e-002

$17 / 09 / 201916.32$

\begin{tabular}{|l|}
\hline $\mathbf{0 , 4 5 3 1 3}$ Max \\
0,40278 \\
0,35243 \\
0,30209 \\
0,25174 \\
0,20139 \\
0,15105 \\
0,1007 \\
0,050352 \\
$\mathbf{5 , 0 8 1 1 e - 6}$ Min
\end{tabular}
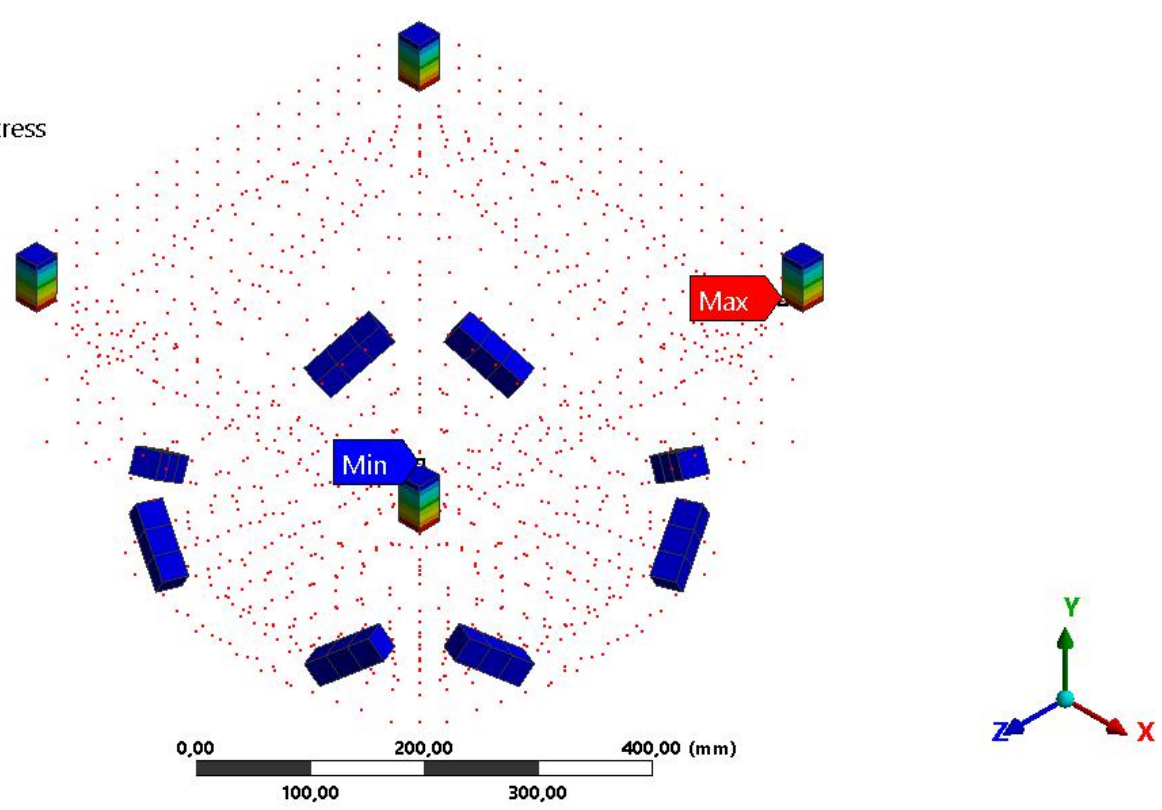

(a) 


\section{E: $25 \mathrm{MPa}$}

Maximum Principal Stress

Type: Maximum Principal Stress Unit: MPa

Time: 2,5004e-002

$17 / 09 / 201916.33$

\begin{tabular}{|l|}
$\mathbf{0 , 9 0 5 0 6}$ Max \\
0,80499 \\
0,70491 \\
0,60483 \\
0,50476 \\
0,40468 \\
0,30461 \\
0,20453 \\
0,10445 \\
$\mathbf{0 , 0 0 4 3 7 8 8}$ Min
\end{tabular}
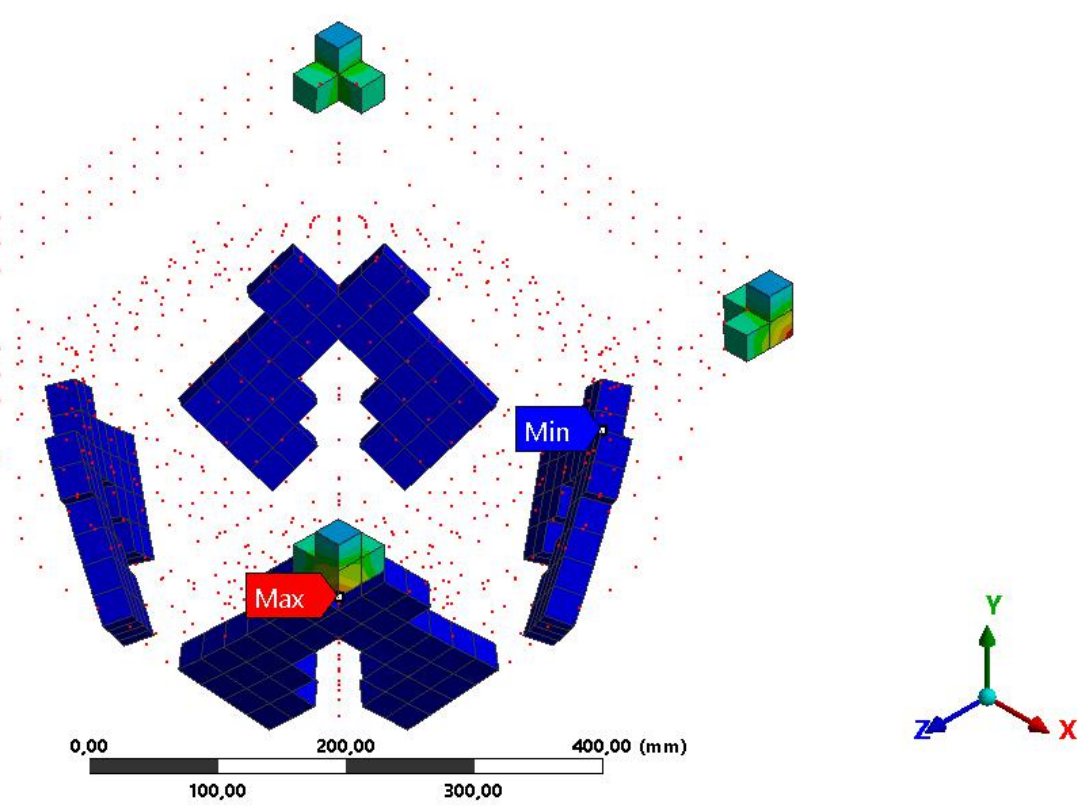

(b)
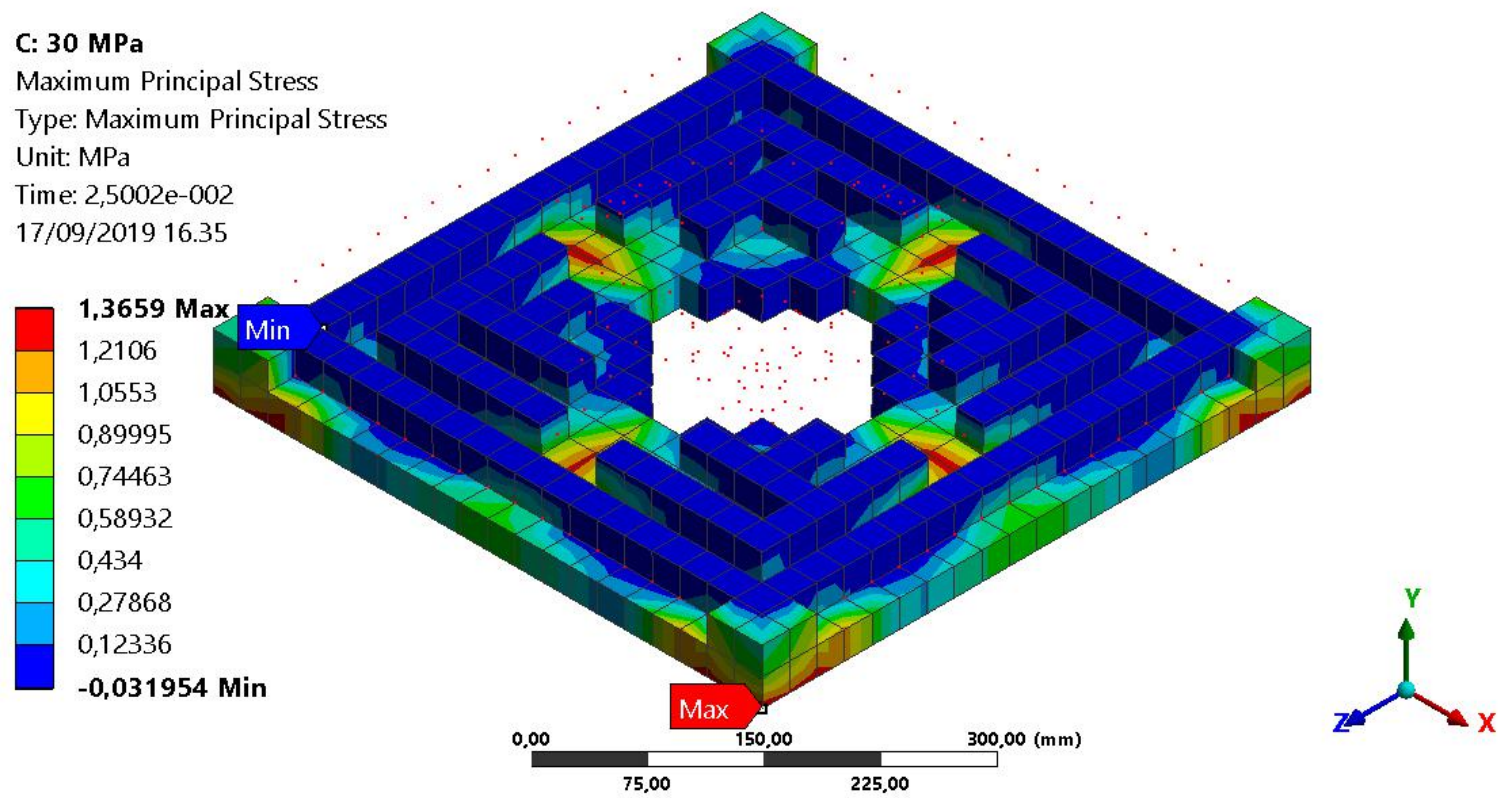

(c) 


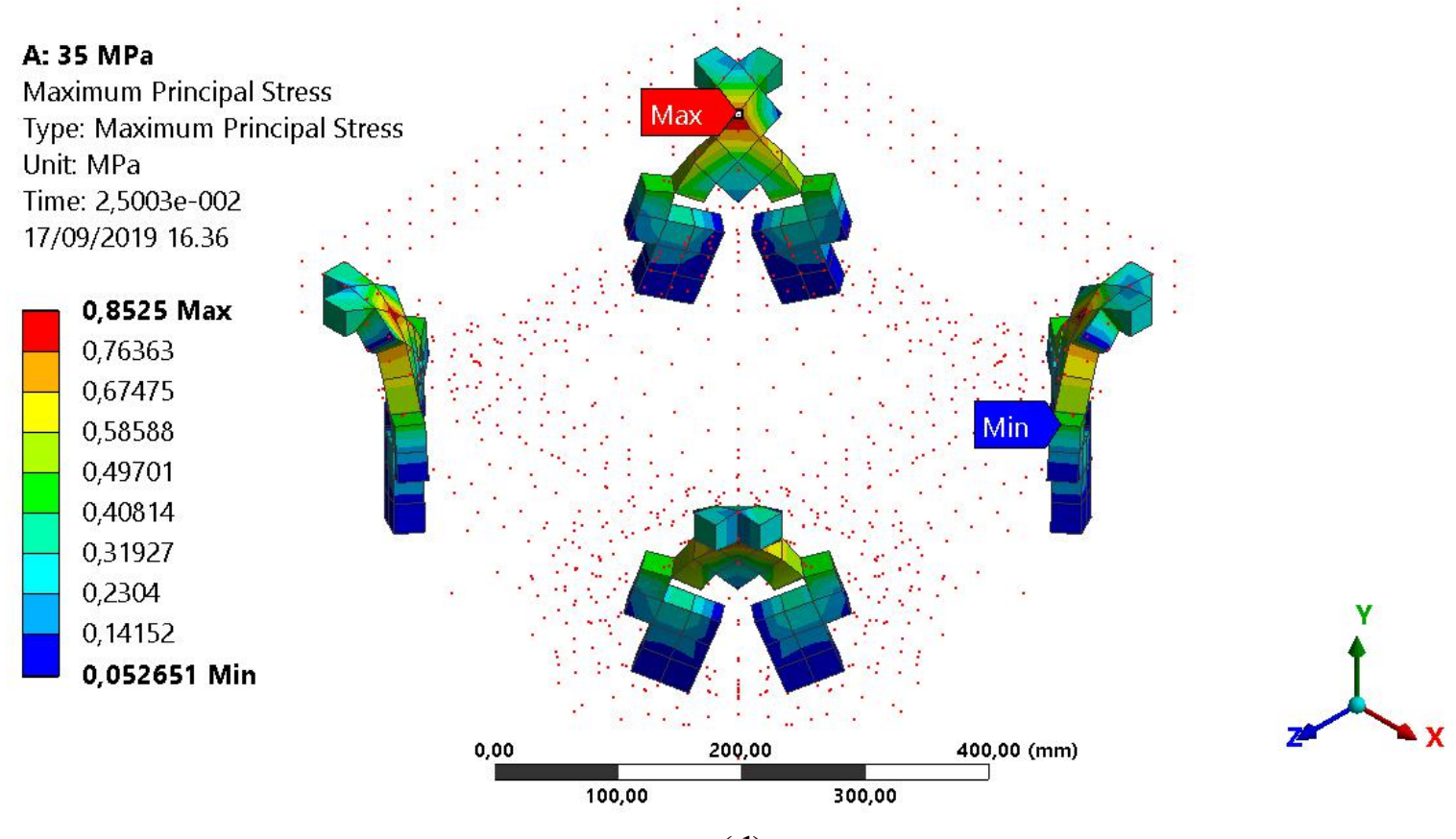

(d)

Figure 4. Numerical results using $z 1 \mathrm{~m} / \mathrm{kg}^{1 / 3}$ with given compressive strength: (a) $20 \mathrm{MPa}$; (b) $25 \mathrm{MPa}$; (c) $30 \mathrm{MPa}$; (d) $35 \mathrm{MPa}$

Figure 4 Shows the result of explosion from 125 grams TNT. The damage was shown on all slab. However, $30 \mathrm{MPa}$ slab is the least damaged. These break down affected the value of tensile stress in each slab. The maximum stress shown on each Figure was not on the same spot. Therefore, those values should not be compared. This result gave the small conclusion: None slab resisted the explosion from 125 grams TNT.

The simulation process was repeated on decreasing charge's mass, respectively. Finally, 30 grams TNT was selected. Using eq. (1) the scaled distance $z$ is $1.6 \mathrm{~m} / \mathrm{kg} 1 / 3$. The minimum compressive strength of slab that withstand a 30 grams TNT is $20 \mathrm{MPa}$. The next step was simulating explosion test on each slab with 30 grams TNT to find the maximum tensile stress. The result is shown in Figure 5.

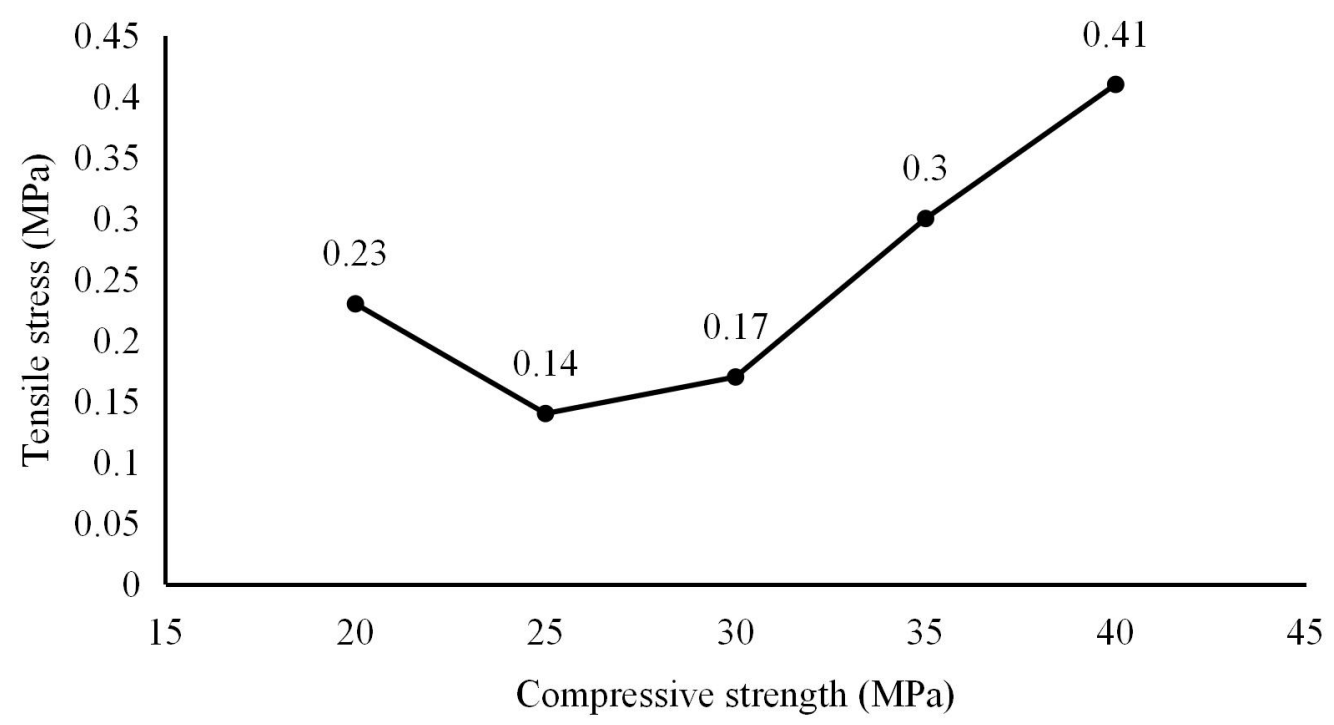

Figure 5. Comparison between tensile stress and compressive strength for $z 1.6 \mathrm{~m} / \mathrm{kg}^{1 / 3}$ 
(e)ISSN 2656-8896 (p)ISSN 2656-890X

Journal of Infrastructure and Facility Asset Management - Vol. 1, Issue. 2, September 2019

\section{E: $20 \mathrm{MPa}$}

Normal Stress

Type: Normal Stress(Y Axis)

Unit: MPa

Global Coordinate System

Time: 5,0002e-003

$12 / 04 / 201921.51$
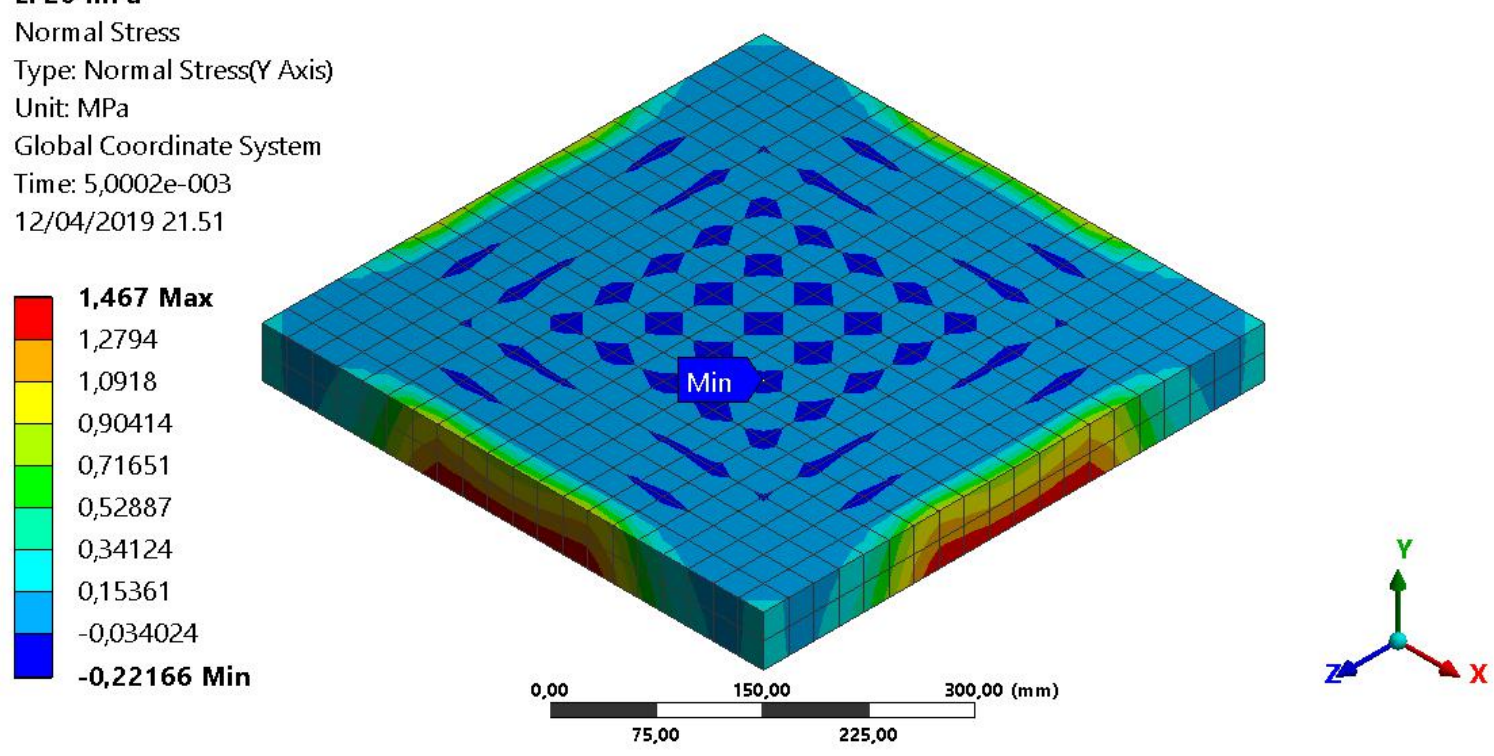

(a)

\section{D: $25 \mathrm{MPa}$}

Normal Stress

Type: Normal Stress(Y Axis)

Unit: MPa

Global Coordinate System

Time: 5,0021e-003

17/09/201916.39
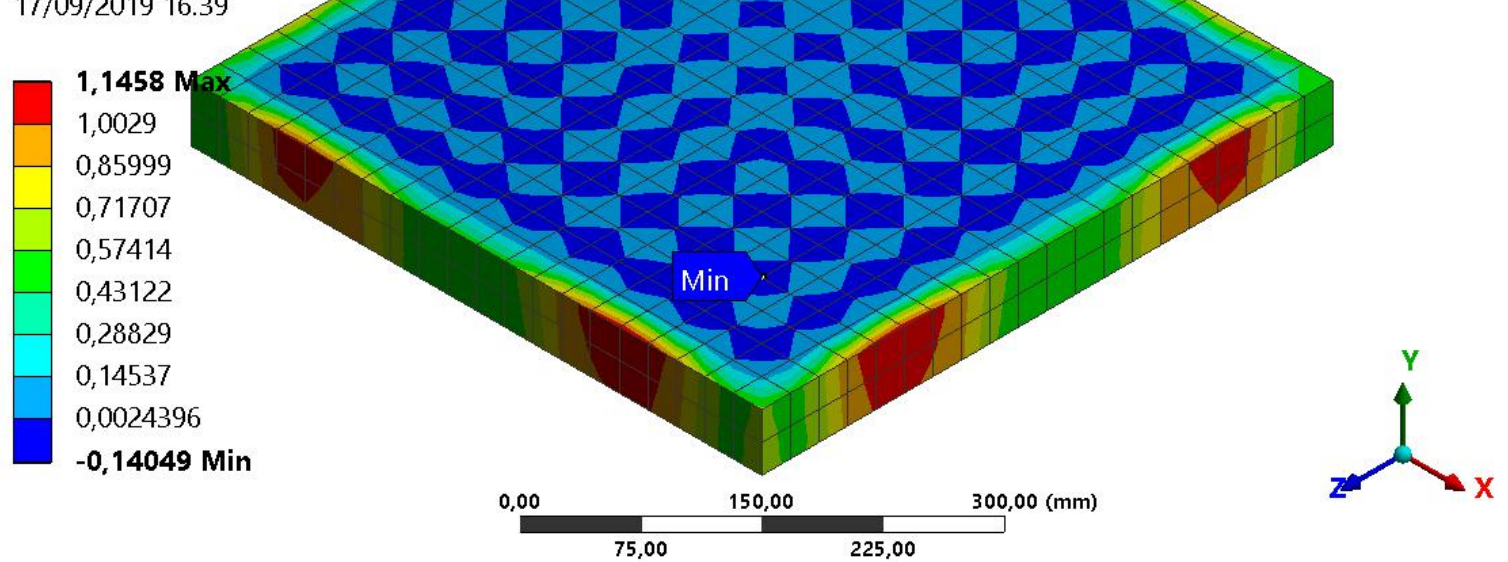

(b) 


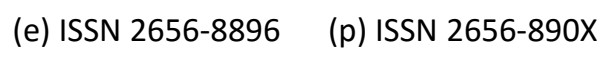

Journal of Infrastructure and Facility Asset Management - Vol. 1. Issue. 2, September 2019

\section{B: $30 \mathrm{MPa}$}

Normal Stress

Type: Normal Stress(Y Axis)

Unit: MPa

Global Coordinate System

Time: 5,0035e-003

12/04/201921.54

\begin{tabular}{|l|l|}
\hline 2,3936 & Max \\
2,1084 \\
1,8232 \\
1,538 \\
1,2528 \\
0,96765 \\
0,68247 \\
0,39728 \\
0,1121 \\
$-\mathbf{0 , 1 7 3 0 8}$ Min
\end{tabular}
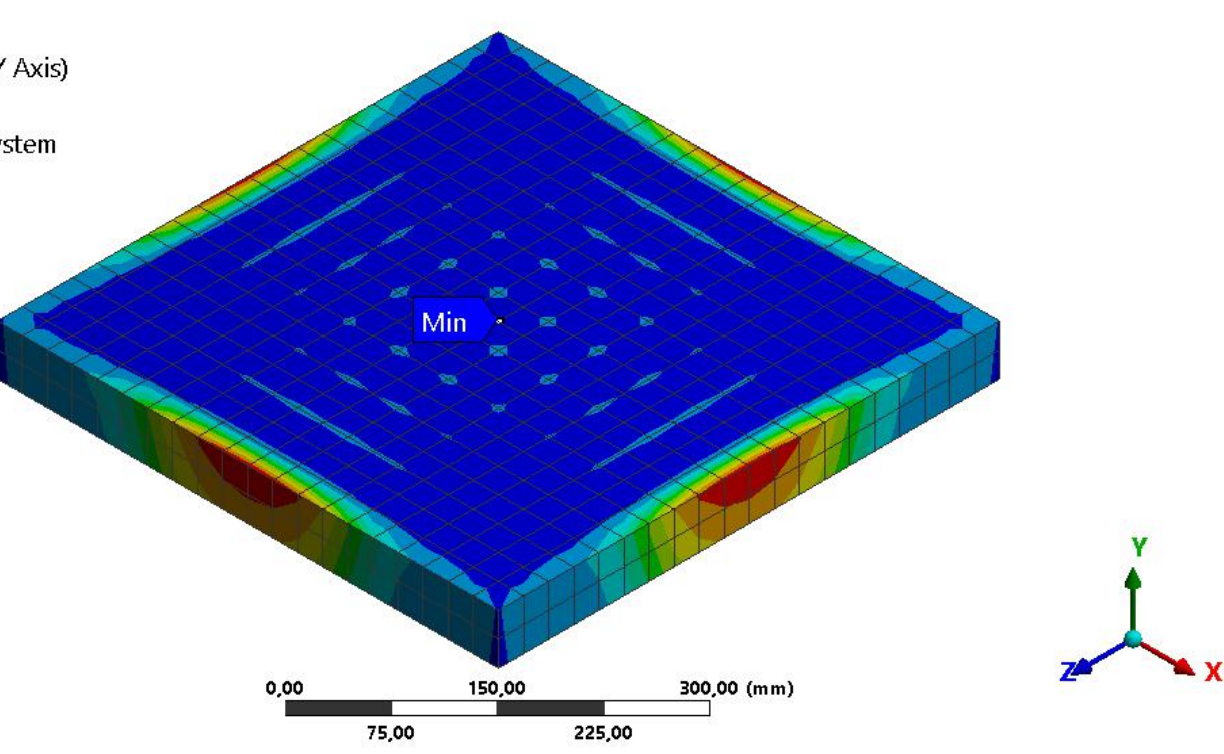

(c)

\section{A: $35 \mathrm{MPa}$}

Normal Stress

Type: Normal Stress(Y Axis)

Unit: MPa

Global Coordinate System

Time: 5,0008e-003

$12 / 04 / 201921.54$
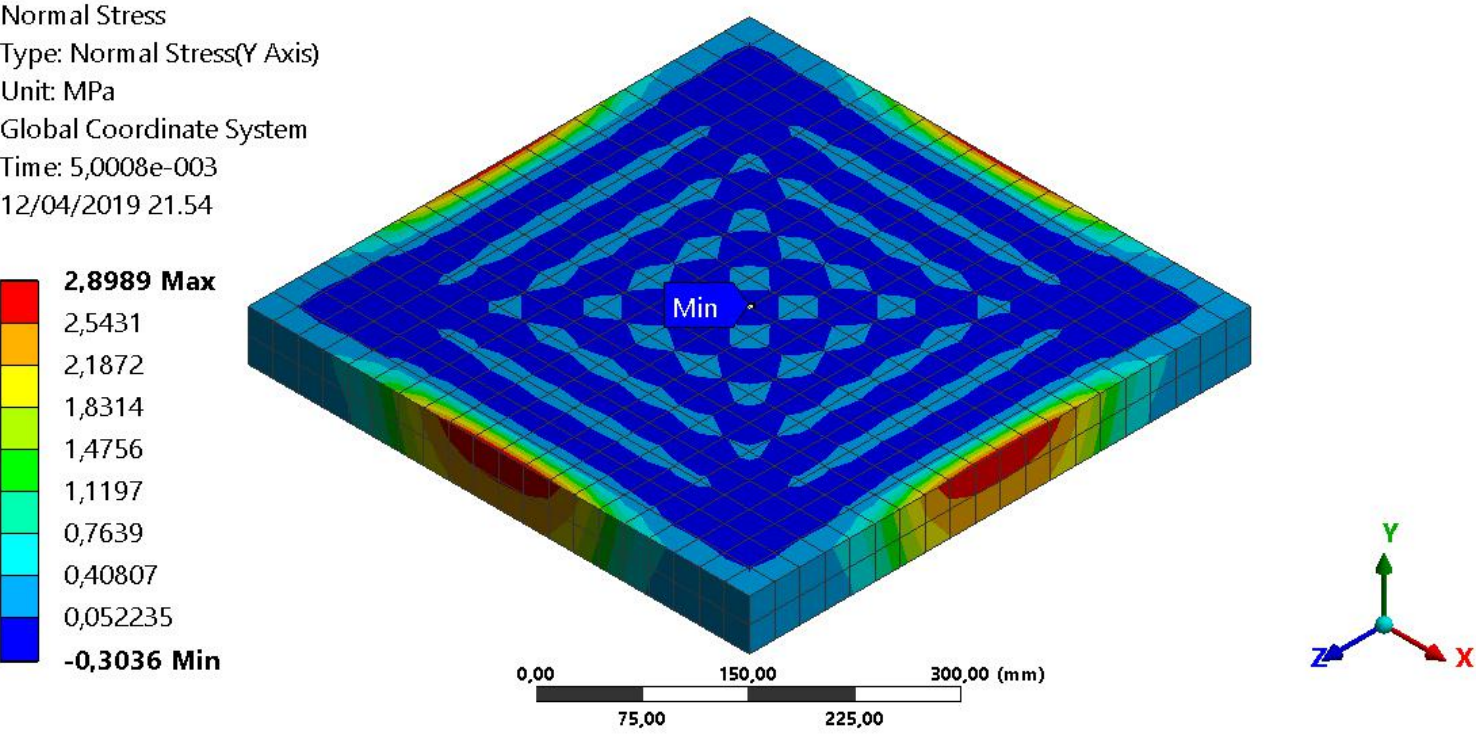

(d) 

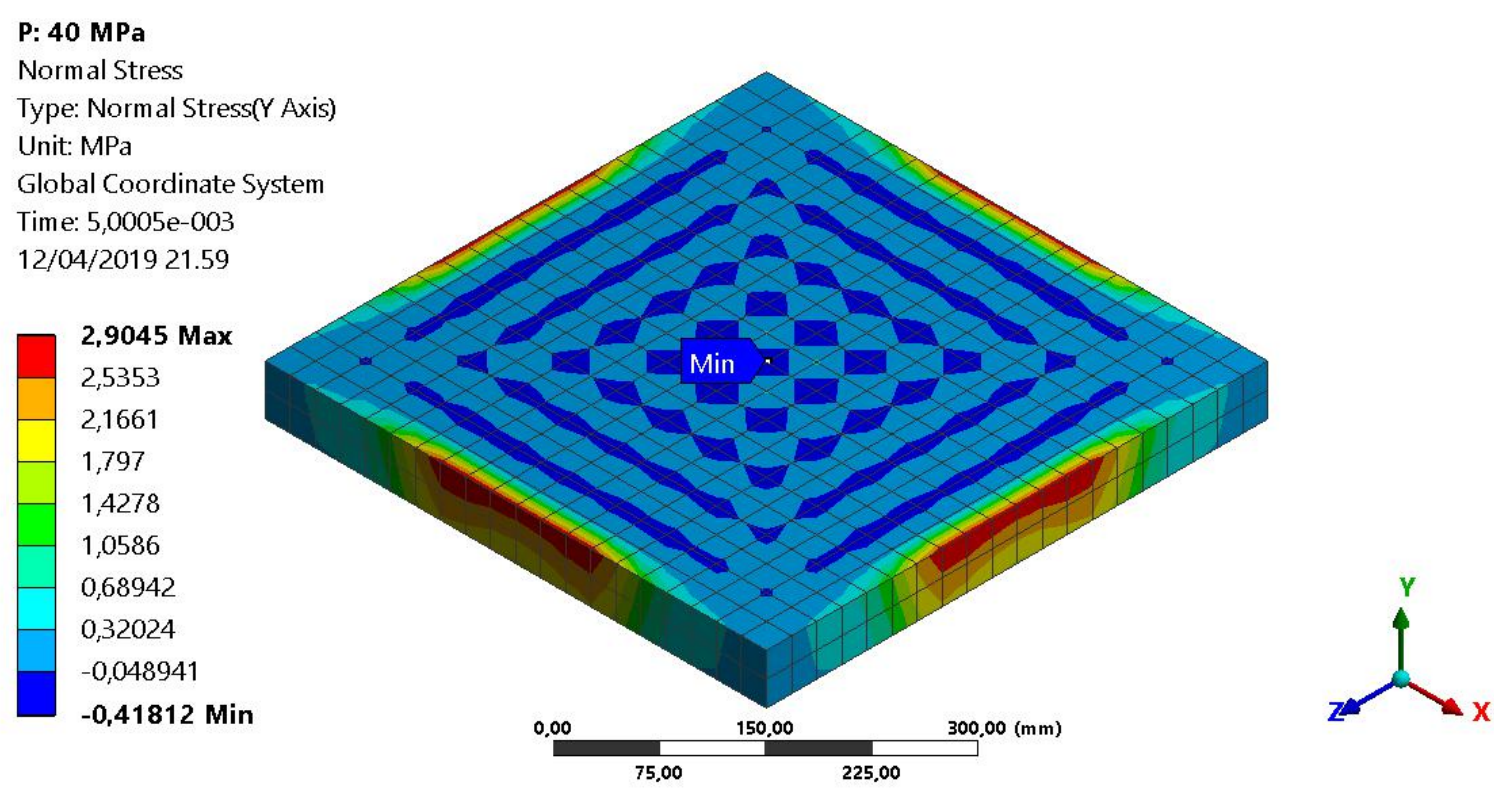

(e)

Figure 6. Simulation result using $z 1,6 \mathrm{~m} / \mathrm{kg} 1 / 3$ on each slab with given compressive strength: (a) $20 \mathrm{MPa}$; (b) $25 \mathrm{MPa}$; (c) $30 \mathrm{MPa}$; (d) $35 \mathrm{MPa}$; (e) $40 \mathrm{MPa}$

All slab shown in Figure 6 did not damage. From Figure 5, it was shown that the smallest tensile stress was the most resistance against 30 grams TNT explosion. The smallest tensile stress falls on $25 \mathrm{MPa}$ slab. It is considered the optimum compressive strength for slab to resist blast load from 30 grams TNT. It proved that the best ductility was provided in compressive strength around 20-25 MPa. Ductility is the main role in absorbing impulse energy (U.S. Department of Defense, 2008). However, the tensile stress increase from 25 $\mathrm{MPa}$. It is assumed that the ductility decrease as the compressive strength rise greater than 25 $\mathrm{MPa}$.

The second step was finding the minimum of explosion resistance based on explosive charge's mass on different compressive strength. Trial and error method was applied on each specimen. This method applied on each charge's mass in descending order. The result is shown in Table 2.

Table 2. Maximum TNT mass on each slab

\begin{tabular}{ccccc}
\hline \hline $\begin{array}{c}\text { Compressive } \\
\text { strength }(\mathrm{MPa})\end{array}$ & $\begin{array}{c}\text { Tensile Strength } \\
(\mathrm{MPa})\end{array}$ & $\begin{array}{c}\text { Mass of TNT } \\
(\text { grams })\end{array}$ & $\begin{array}{c}\text { tensile stress } \\
(\mathrm{Mpa})\end{array}$ & $\begin{array}{c}\text { Deformation } \\
(\mathrm{mm})\end{array}$ \\
\hline 20 & 2 & 30 & 0.23 & 0.57 \\
25 & 2,5 & 40 & 0.13 & 0.13 \\
30 & 3 & 45 & 0.67 & 1,1 \\
35 & 3,5 & 45 & 1,9 & 1,94 \\
40 & 4 & 55 & 0.41 & 0.84 \\
\hline
\end{tabular}




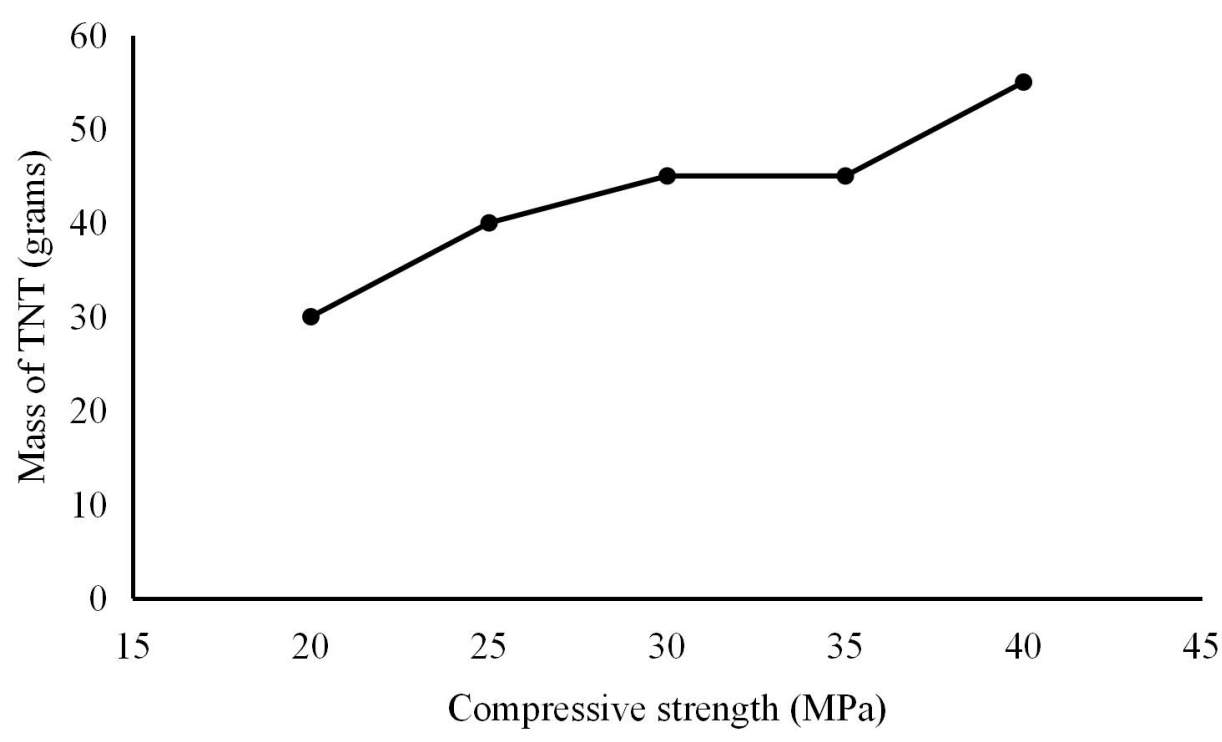

Figure 7. Comparison between TNT mass and compressive strength

Figure 7 showed that the explosion resistance is increased as the compressive strength increase. This assumption indicated that there is a linear connection between TNT mass and compressive strength. However, from the result in Figure 5, the optimum compressive strength for 30 grams TNT is on $25 \mathrm{MPa}$. Based on the assumption in the first step, the compressive strength greater than $25 \mathrm{MPa}$ resist the blast load from smaller mass due to the increased rigidity. Figure 7 showed otherwise. This contradictory statement requires further observation.

The last step was comparing Young modulus from designed concrete and sample concrete from experiment (Al Bari, et al., 2019) called steel fiber concrete (SFC). Steel fiber behavior in SFC is ignored.Young modulus for designed concrete was calculated from eq. (3). The data for SFC is shown in Table 3. SFC had lower Young modulus and different Poisson's ratio than the designed concrete.

Table 3. Comparison of material properties between designed concrete and steel fiber concrete (SFC)

\begin{tabular}{|c|c|c|c|c|c|}
\hline \multicolumn{3}{|c|}{$f_{c}^{\prime} 30.88 \mathrm{MPa}$} & \multicolumn{3}{|c|}{$f_{c}^{\prime} 33,47 \mathrm{MPa}$} \\
\hline Design & & SFC & sign & & SFC \\
\hline 3,88 & 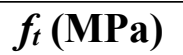 & & & Jt & \\
\hline $2611^{\prime}$ & & 9 & 91 & & 2105 \\
\hline 0.15 & $P$ & 0.21 & .15 & Poi & 0.19 \\
\hline 55 & 0 (IV & or & 822 & & 888 \\
\hline \multicolumn{3}{|c|}{$f_{c}^{\prime} 31,84(\mathrm{MPa})$} & \multicolumn{3}{|c|}{$f_{c} 35,12 \mathrm{MPa}$} \\
\hline Design & & SFC & Design & & SFC \\
\hline 3,88 & & 5,41 & 3,88 & & 6,29 \\
\hline 26520 & $E$ (MPa) & 20492 & 27853 & $E$ (MPa) & 21519 \\
\hline 0.15 & Poisson & 0.19 & 0.15 & Poisson & 0.17 \\
\hline 11530 & $G(\mathrm{MPa})$ & 8610 & 12110 & $G(\mathrm{MPa})$ & 9196 \\
\hline
\end{tabular}


B: GC $30,8 \mathrm{MPa}$

Normal Stress

Type: Normal Stress(Y Axis)

Unit: MPa

Global Coordinate System

Time: 2,5001e-002

16/09/2019 11.16

\begin{tabular}{|l|l}
\hline $\mathbf{1}, 1352$ Max \\
0,99561 \\
0,856 \\
0,71639 \\
0,57677 \\
0,43716 \\
0,29755 \\
0,15793 \\
0,018318 \\
$-0,1213$ Min
\end{tabular}
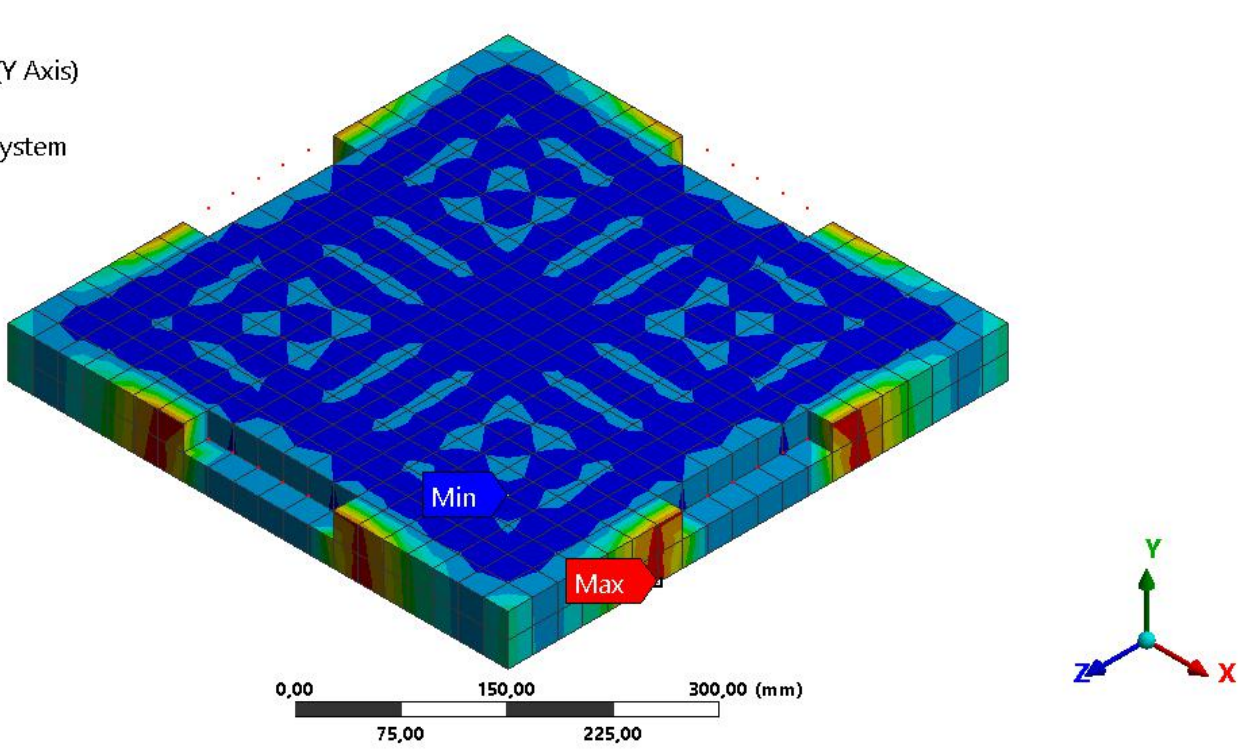

(a)

\section{J: GC 31,84 MPa}

Maximum Principal Stress

Type: Maximum Principal Stress

Unit: $\mathrm{MPa}$

Time: 2,5e-002

16/09/201911.01

\begin{tabular}{|l}
$\mathbf{3}, 5297$ Max \\
3,1349 \\
2,7401 \\
2,3452 \\
1,9504 \\
1,5556 \\
1,1608 \\
0,76592 \\
0,3711 \\
$-\mathbf{0 , 0 2 3 7 2 8}$ Min
\end{tabular}
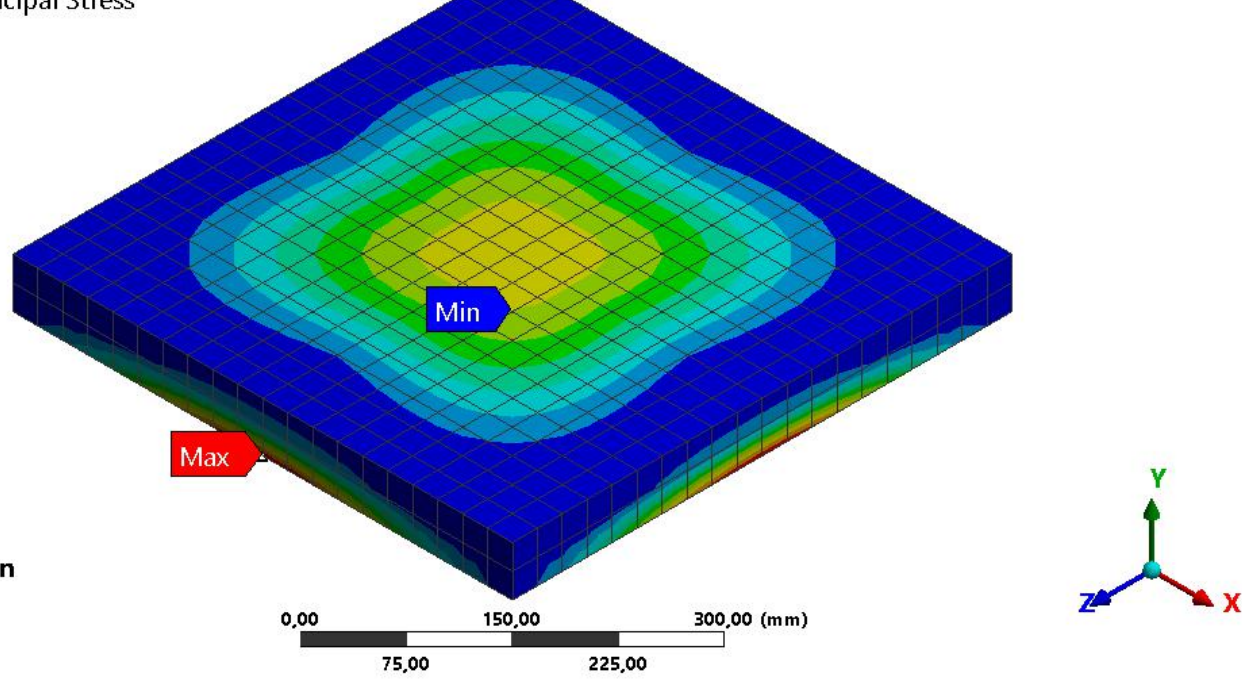

(b) 


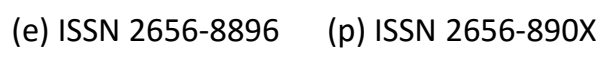

Journal of Infrastructure and Facility Asset Management - Vol. 1. Issue. 2, September 2019
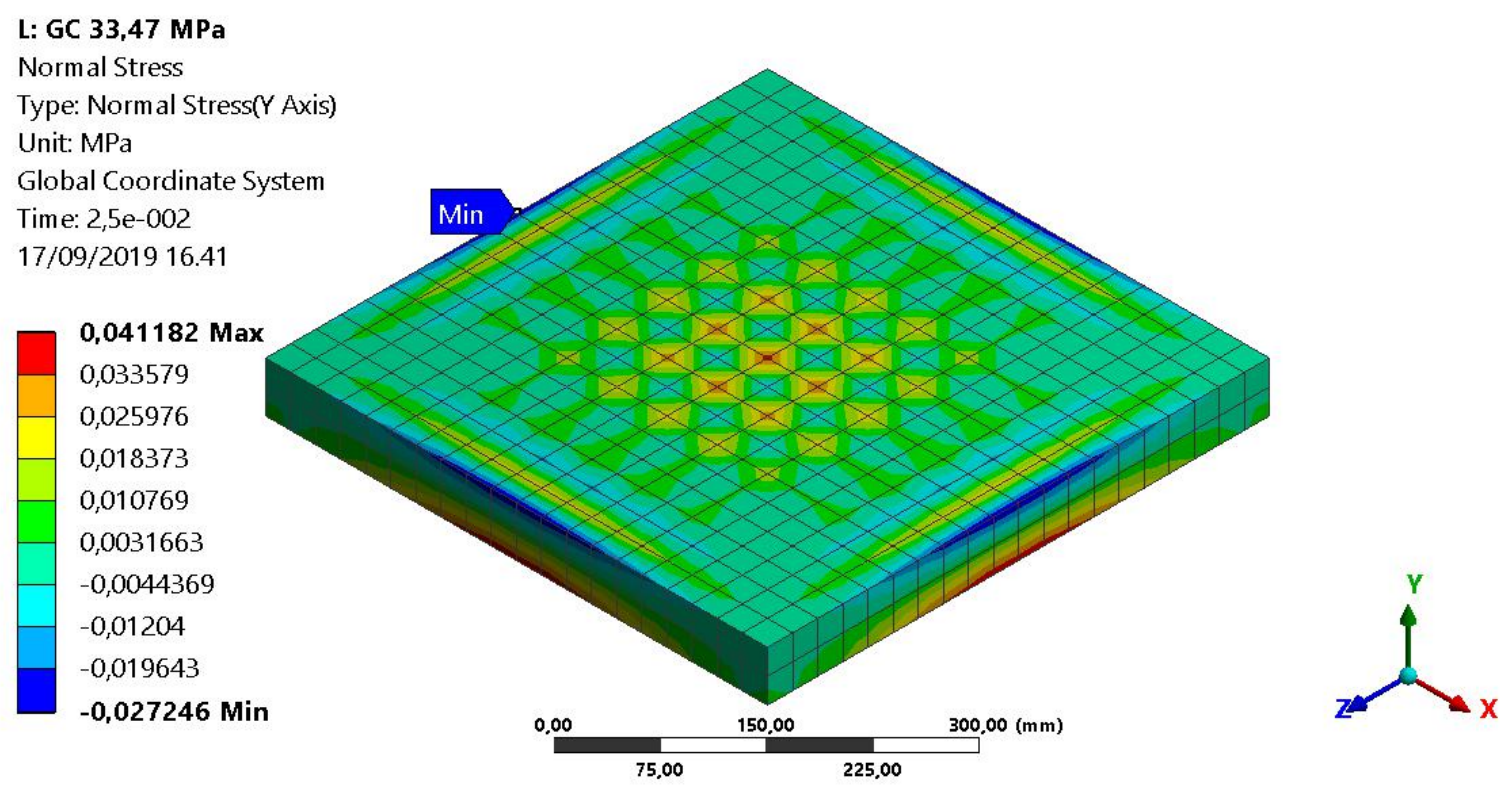

(c)
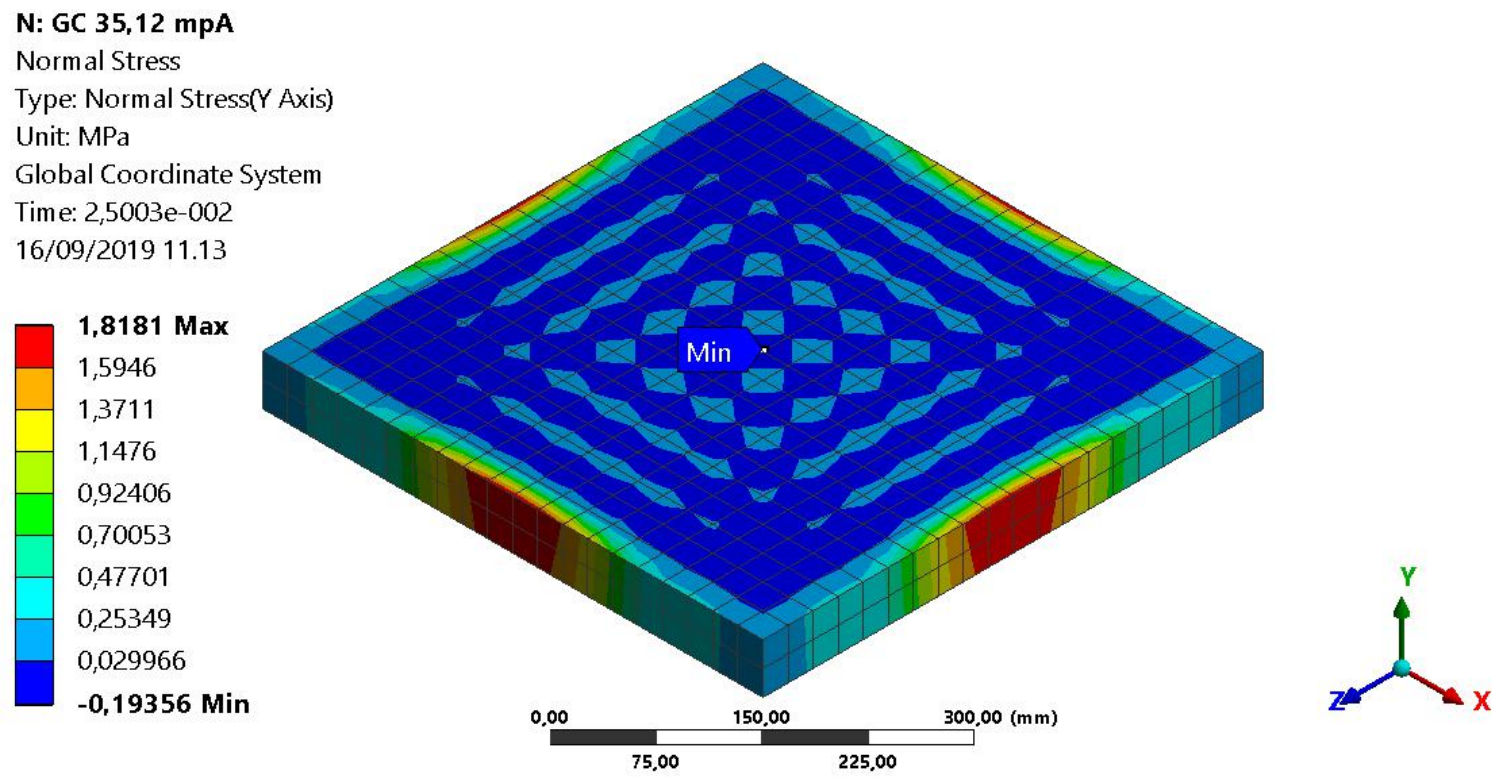

(d)

Figure 8. Simulation result using $z 1,6 \mathrm{~m} / \mathrm{kg} 1 / 3$ on each slab with SFC material with a compressive strength of: (a) $30.88 \mathrm{MPa}$, (b) $31,84 \mathrm{MPa}$, (c) $33,47 \mathrm{MPa}$, (d) $35,12 \mathrm{MPa}$

Figure 8 shows the result of simulation on experiment concrete. The tensile stress on each sample was taken on the same spot where is located at the center slab. The tensile stress is compared as shown in Figure 9. On the contrary, another non-consistent result is shown in Figure 8(a) where the weakest slab is even damaged due to smaller TNT. This result is in accordance with $\mathrm{Tu}$ (Tu \& Lu, 2010). It was stated that RHT Concrete failed to represent the concrete behavior, mainly on tension response and softening behavior under some loading condition. Thus, he recommended modifying the RHT concrete model from ANSYS database. 


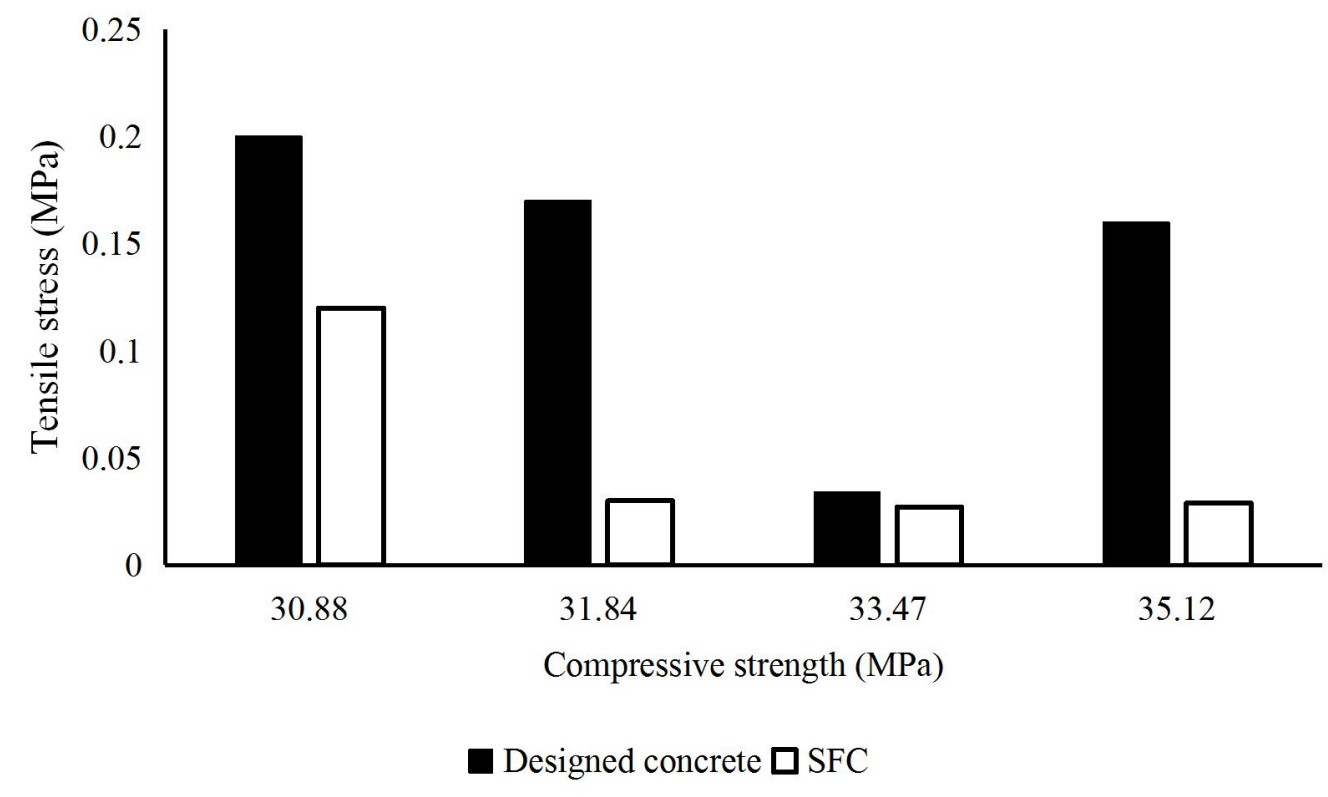

Figure 9. Comparison of tensile stress between designed concrete material and experiment concrete material

From Figure 9, it was found that the observed concrete had lower tensile stress than the designed. Small tensile stress on the slab showed that the concrete had better explosion resistance than designed concrete.

\section{Validation}

Validation is an important step on explosive simulation. The purpose is to compare the result from a numerical program with theory. If the result is compatible, the numerical result is considered valid.

Blast loading validation is needed to confirm the performance of ANSYS Workbench. Validation test model is identical to Figure 3 with modified calculation method on explosive charge. Calculation method on TNT was changed from Lagrangian (standard) to Eulerian. The virtual area from Eulerian method was deployed as shown in Figure 10 to observe explosive behavior. Simulation was performed three times on $z 0.5 \mathrm{~m} / \mathrm{kg} 1 / 3,0.75 \mathrm{~m} / \mathrm{kg} 1 / 3,1$ $\mathrm{m} / \mathrm{kg} 1 / 3$ to retrieve peak incident pressure $\left(P_{o}\right)$. The result was compared with calculation in Figure 2 by using the same $z$ parameter. The comparison is shown in table 4 .
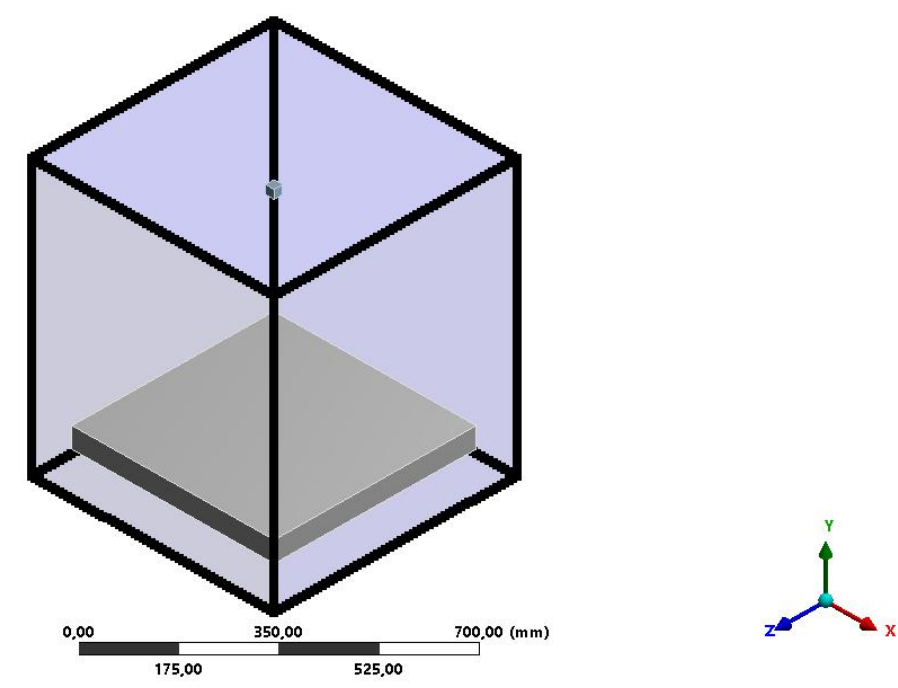

Figure 10. Virtual area of Eulerian in validation model 


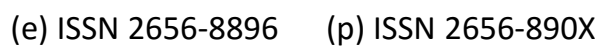

Journal of Infrastructure and Facility Asset Management - Vol. 1. Issue. 2, September 2019

Table 4. Blast pressure validation result

\begin{tabular}{cccccc}
\hline $\begin{array}{c}z \\
\left(\mathrm{~m} / \mathrm{kg}^{1 / 3}\right)\end{array}$ & $\begin{array}{c}\text { Range } \\
(\mathrm{m})\end{array}$ & $\begin{array}{c}\text { Mass } \\
(\mathrm{kg})\end{array}$ & $\begin{array}{c}\text { Peak Incident } \\
\text { Pressure }(\mathrm{MPa})\end{array}$ & $\begin{array}{c}\text { Maximum Tensile } \\
\text { stress }(\mathrm{MPa})\end{array}$ & $\begin{array}{c}\text { Deviation } \\
(\%)\end{array}$ \\
\hline 0.5 & 0.5 & 1 & 15,17 & 16 & 5,47 \\
0.75 & 0.5 & 0.296 & 9,52 & 10.28 & 7,98 \\
1 & 0.5 & 0.125 & 5,51 & 4,94 & 10.34 \\
\hline \hline
\end{tabular}

Table 4 showed relevance between numerical and theory. However, ANSYS could not show pressure-time graph of explosion. We obtained that ANSYS Workbench performed explosive simulation well although the results were inconsistent when the concrete properties was modified. The less damaged slab in Figure 4(c) and damaged slab in Figure 8(a) showed the numerical process instability in ANSYS Workbench. Contradictory result on the first and second simulation provided great evidence. Further research is needed to find the cause of instability in ANSYS Workbench analysis program whether in the numerical formula or in RHT concrete properties. In addition, other numerical program is needed to compare its stability of a numerical formula with ANSYS Workbench's.

\section{CONCLUSION}

The conclusion from this study about Simulation of Concrete Slab Behavior to Explosion is shown below.

1. $500 \times 500 \times 50 \mathrm{~mm}$ slab with compressive strength minimum $20 \mathrm{MPa}$ had resistance against explosion from 30 grams TNT.

2. Young modulus affects greatly to the concrete behavior to explosion.

3. ANSYS Workbench using default RHT Conrete properties had instability againts modified concrete properties when performing numerical analysis.

\section{BIBLIOGRAPHY}

Al Bari, M. S., Ekaputri, J. J., F. \& Ariatedja, J. B. (2019). Simulation of Steel Fibre Reinforced Concrete Behavior to Explosion. Final Project. Unpublished. Faculty of Civil, Environmental and Geo Engineering. Institut Teknologi Sepuluh Nopember. Surabaya.

BSN (2013). Persyaratan Beton Struktural untuk Bangunan Gedung. SNI 2847-2013. BSN Badan Standarisasi Nasional.

FEMA (2003). Primer for Design of Commercial Buildings to Mitigate Terrorist Attacks. Risks Management Series. FEMA 427. FEMA - Federal Emergency Management Agency.

Koccaz, Z., Sutku, F. \& Torunbalci, N. (2008). “Architectural and Structural Design for Blast Resistant Building”. The $14^{\text {th }}$ Conference on Earthquake Engineering, October 12-17, 2018. Beijing.

Lee, H.-H. (2015). Finite Element Simulation with ANSYS Workbench 16. SDC Publication.

Nayel, A. G. \& Abdel-mooty, M. (2017). "Numerical simulation of reinforced concrete panels under the effect of unconfined external detonations". 2nd International Conference on Structural Safety under Fire \& Blast Loading CONFAB 2017. London. pp. 118-127.

Ngo, T., Mendis, P., Gupta, A. \& Ramsay, J. (2007). "Blast Loading and Blast Effects on Structures - An Overview". EJSE Special Issue: Loading on Structures, (pp. 76-91).

Remennikov, A. \& Carolan, D. (2006). "Blast Effects and Vulnerability of Building Structures from Terrorist Attack". Australian Journal of Structural Engineering, Vol. 7, No. 1, 2006. 
Riedel, W., Kawai, N. \& Kondo, K.-i. (2009). "Numerical Assessment for Impact Strength Measurements in Concrete Materials". International Journal of Impact Engineering, (pp. 283-293).

Shi, Y., Hao, H. \& Li, Z.-X. (2007). "Numerical simulation of blast wave interaction with structure columns". Shock Waves, (pp. 113-133).

Suprayitno, H. \& Soemitro, R.A.A. (2018). "Preliminary Reflexion on Basic Principle of Infrastructure Asset Management”. Jurnal Manajemen Aset Infrastruktur \& Fasilitas, Vol. 2, No. 1, Maret 2018.

Suprayitno, H. \& Soemitro, R.A.A. (2019). "Reflection on Basic View of Public Infrastructure for Infrastructure Asset Management in Indonesia”. Jurnal Manajemen Aset Infrastruktur \& Fasilitas, Vol. 3, Suplemen 1, Juni 2019.

Tu, Z. \& Lu, Y. (2010). "Modifications of RHT material model for improved numerical simulation of dynamic response of concrete". International Journal of Impact Engineering.

U.S. Department of Defense (2008). Structures to Resist The Effects of Accidental Explosions. UFC 3-340-02. U.S. Department of Defense.

Wang, F. et al. (2008). "Reinforced concrete slab subjected to close-in explosion". DYNAmore. Bamberg. pp. J - I - 21. 